SCIENCE ON STAGE IN EARLY MODERN SPAIN 
This page intentionally left blank 


\section{Science on Stage in Early Modern Spain}

EDITED BY

ENRIQUE GARCÍA SANTO-TOMÁS 
(C) University of Toronto Press 2019

Toronto Buffalo London

utorontopress.com

Printed in the U.S.A.

ISBN 978-1-4875-0405-2

( Printed on acid-free paper with vegetable-based inks.

\section{Library and Archives Canada Cataloguing in Publication}

Science on stage in early modern Spain / edited by Enrique García Santo-Tomás.

(Toronto Iberic ; 38)

Includes bibliographical references.

ISBN 978-1-4875-0405-2 (hardcover)

1. Spanish drama - Classical period, 1500-1700 - History and criticism.

2. Theater - Spain - History - 16th century. 3. Theater - Spain - History 17th century. 4. Science - Spain - History -16 th century. 5. Science Spain - History - 17th century. 6. Science in literature. I. García SantoTomás, Enrique, editor II. Series: Toronto Iberic; 38

PQ6105.S35 2019 862'.309 C2018-905256-2

University of Toronto Press acknowledges the financial assistance to its publishing program of the Canada Council for the Arts and the Ontario Arts Council, an agency of the Government of Ontario.

Council for the Arts

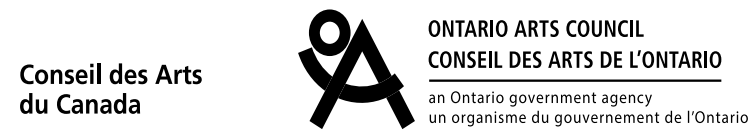


To Mercedes Alcalá-Galán and Steven Hutchinson, in friendship 
This page intentionally left blank 